Diabetologia 6, 499-504 (1970)

\title{
Assay of Insulin-Like Activity by the Isolated Fat Cell Method IV. The Biological Activity of Proinsulin*
}

\author{
J. GLimManN and H.H. Sørensen
}

Institute of Medical Physiology C, Copenhagen, Denmark

Received: March 6, 1970

Summary. The effect of bovine proinsulin and related factors on the glucose metabolism of isolated, rat, fat cells was studied. The dose-response curve of proinsulin was parallel to that of insulin and the action of the two proteins showed an identical time course. The activity of single chain proinsulin was about $0.5 \mathrm{U} / \mathrm{mg}$ (as estimated from its ability to increase the conversion of ${ }^{14} \mathrm{C}$-glucose to ${ }^{14} \mathrm{CO}_{2}$ or to ${ }^{14} \mathrm{C}$-glycerides by fat cells) and rose to about $17 \mathrm{U} / \mathrm{mg}$ after treatment with trypsin. - The activity of insulin was quantitatively recovered in the presence of proinsulin. Split chain proinsulin showed an activity of $5 \mathrm{U} / \mathrm{mg}$, which rose to about $18 \mathrm{U} / \mathrm{mg}$ after treatment with trypsin. Connecting peptide did not influence the glucose metabolism in the absence or presence of insulin. - There was no conversion of proinsulin in the isolated cell incubation medium to insulin or a similar molecule with high biological activity. The activity was the same on rat epididymal fat pads as on isolated fat cells, and there was no significant suppression by Kunitz panereatic trypsin inhibitor in either system. - The following was concluded: the biological activity of proinsulin on rat isolated fat cells and epididymal fat pads is about 2 per cent of that of insulin, and the effect is caused by the proinsulin molecule itself. The reason for the low biological activity is presumably a smaller affinity for insulin receptors.

Dosage de l'activité insulinique par la méthode des cellules adipeuses isolées. IV. L'activité biologique de la proinsuline

Résumé. L'effet de la proinsuline bovine et de facteurs analogues sur le métabolisme glucidique de cellules adipeuses isolées de rat a été étudié. La courbe dose-réponse de la proinsuline était parallèle à celle de l'insuline et l'action des deux protéines montrait une évolution dans le temps identique. L'activité de la proinsuline à chaîne unique était d'environ $0.5 \mathrm{U} / \mathrm{mg}$ (calculée d'après sa capacité à augmenter la conversion de glucose ${ }^{14} \mathrm{C}$ en ${ }^{14} \mathrm{CO}_{2}$ ou en glycérides ${ }^{14} \mathrm{C}$ par des cellules adipeuses) et montait à environ $17 \mathrm{U} / \mathrm{mg}$ après traitement avec de la trypsine. L'activité de l'insuline a été retrouvée quantita. tivement en présence de proinsuline. La proinsulineà chaîne rompue montrait une activité de $5 \mathrm{U} / \mathrm{mg}$ qui s'élevait à $18 \mathrm{U} / \mathrm{mg}$ après traitement par la trypsine. Le polypeptide de connexion n'influençait pas le métabolisme glucidique avec ou sans insuline. Dans le milieu d'incubation, il n'y avait pas de conversion de proinsuline en insuline ou en une molécule comparable avec une activité biologique élevée. L'activité était la même avec du tissu adipeux épididymaire de rat qu'avec des cellules adipeuses isolées et il $n^{\prime} y$ avait pas de suppression significative par l'in. hibiteur de trypsine pancréatique de Kunitz dans aucun des deux systèmes. Nous sommes arrivés aux conclusions suivantes : L'activité biologique de la proinsuline sur des cellules adipeuses isolées du rat et sur le tissu adipeux épididymaire correspond à environ $2 \%$ de celle de l'insuline et l'effet est causé par la molécule de proinsuline elle-même. La raison pour cette activité biologique basse est probablement une affinité réduite pour les récepteurs de l'insuline.

Untersuchungen der Insulin-ähnlichen Altivität an isolierten Fettzellen. IV. Die biologische Aktivität von Proinsulin

Zusammenfassung. Die Wirkung von Rinderproinsulin und verwandter Faktoren auf den Glucosestoffwechsel von isolierten Ratten-Fettzellen wurde untersucht. Die Dosis-Wirkungskurve von Proinsulin verlief parallel zu der von Insulin, und die Einwirkung beider Proteine zeigte einen identischen Zeitablauf. Die Aktivität von einkettigem Proinsulin betrug etwa $0.5 \mathrm{E} / \mathrm{mg}$ (wie aus seiner Fähigkeit geschlossen wurde, die Umwandlung von ${ }^{14} \mathrm{C}$ Glucose in ${ }^{14} \mathrm{CO}_{2}$ oder ${ }^{14} \mathrm{C}$-Glyceride in Fettzellen zu steigern), und erhöhte sich nach Trypsinbehandlung auf etwa $17 \mathrm{E} / \mathrm{mg}$. - In Gegenwart von Proinsulin ließ sich die Aktivität von Insulin quantitativ wiederfinden. Proinsulin mit gesprengter Kette wies eine Aktivität von $5 \mathrm{E} / \mathrm{mg}$ auf, die nach Trypsinandauung auf $18 \mathrm{E} / \mathrm{mg}$ anstieg. C-Peptid beeinflußte den Glucosestoffwechsel weder mit noch ohne Insulinzusatz. - In der Inkubationsflüssigkeit von isolierten Zellen ließ sich keine Umwandlung von Proinsulin in Insulin oder ein ähnliches Molokül mit hoher biologischer Aktivität nachweisen. Aktivitätsmessungen am Ratten-Nebenhoden-Fettgewebsanhang erbrachten die gleichen Resultate wie an isolierten Fettzellen, und der Kunitz-Pankreas-Trypsin-Inhibitor führte in keinem der beiden Systeme zu einer signifikanten Hemmung. Es wurden folgende Schlïsse gezogen: Proinsulin weist an isolierten Ratten-Fettzellen und am epididymalen Fettgewebsanhang der Ratte etwa $2 \%$ der biologischen Aktivität von Insulin auf, und der Effekt wird durch das Proinsulin-Molekül selbst hervorgerufen. Der Grund für die niedrige biologische Aktivität ist vermutlich in einer geringeren Affinität zu den Insulin-Receptoren zu suchen.

Key-words: Proinsulin, insulin, connecting peptide, isolated fat cells, epididymal fat pads, bioassay.

\section{Introduction}

The existence of an insulin precursor in the islets of Langerhans was first reported by Steiner et al. (1967).

* Supported in part by: Nordic Insulin Foundation and Novo Foundation. Presented in part at the XIIIth Nordic Physiology Congress, Göteborg, August 1969.
When human islet tumour tissue or isolated islets of the rat pancreas were incubated with tritiated leucine and phenylalanine, radioactivity appeared initially in a protein fraction with a molecular weight of $9000-$ 10000. After about $2 \mathrm{~h}$ of incubation, the labelling of this fraction reached a plateau and radioactivity in- 
creased linearly in the insulin fraction (mol. wt. about 6000 ).

The high mol. wt. fraction, which was named proinsulin by Steiner and his associates, has been isolated from pancreas and insulin preparations of a number of animal species (Steiner, 1967; Yip and Lin, 1967; Steiner et al., 1967; Chance et al., 1968; Steiner and Clark, 1968). It consists of a single polypeptide chain which can be converted by treatment with trypsin to insulin lacking residue 30 at the carboxyl terminal of the B-chain (Steiner et al., 1967). The molecule reacts with guinea pig antiserum to homologous insulin (Steiner et al., 1968). Recently Chance et al. (1968) have deter. mined the amino acid sequence of porcine proinsulin.

It is of interest from the point of view of mechanism of insulin action to determine the biological activity of this single chain proinsulin molecule. In addition, it has been shown that human serum contains a factor with a mol. wt. of about 9000 and with immunological properties similar to insulin (Rubenstein et al., 1968; Roth et al., 1968) or proinsulin (Yip and Logothetopoulos, 1969). This factor has a low biological activity (Gliemann et al., unpublished) and may be identical with proinsulin. It seems likely, therefore, that the study of the biological activity of proinsulin is of physiological significance.

Preliminary studies from this laboratory showed a biological activity of proinsulin of a few per cent of that of insulin (referred to by Steiner et al., 1968). During the present studies, Shaw and Chance (1968) reported that Kunitz pancreatic trypsin inhibitor suppressed the effect of proinsulin, but not of insulin, on rat epididymal fat pads. The authors concluded that proinsulin itself is biologically inactive and that it is converted by adipose tissue enzymes to a molecule similar to or identical with insulin.

For these reasons, the studies reported here have focussed on two questions:

1. Has proinsulin any biological effect on isolated, rat, fat cells which cannot be accounted for by the presence of a trace contamination with insulin?

2. If so, is the activity on isolated fat cells or epididymal fat tissue caused by the proinsulin molecule itself or by a conversion product?

\section{Material and Methods}

The beef proinsulin preparations were obtained through the courtesy of Dr. D.F. Steiner. Three different samples were used: 1 . Single chain proinsulin which had been prepared and purified according to previously published methods (Steiner et al., 1968). 2 . The same preparation which in addition had been reduced by mercaptoethanol in urea $(8 \mathrm{M})$ and reoxidized. 3. Split chain proinsulin, which is identical to the intermediate fraction referred to in the publication of Steiner et al. (1968). The structure of this factor seems to be that of the insulin molecule with the connecting peptide attached to the carboxyl residue of the B-chain but not to the amino residue of the A-chain. The terminal amino acids of the connecting peptide may be lacking (Steiner et al., 1968).

Connecting peptide extracted from beef pancreas was obtained from Novo Research Institute. It must be stressed that this molecule is not identical to the connecting peptide of intact proinsulin, since both the arginine (position 31, 32 and 63) and the lysine residues are lacking (Marcussen, personal communication).

The following materials were gifts from Novo Research Institute: crystalline beef insulin $(24.4 \mathrm{U} / \mathrm{mg})$, guinea pig antibeef-insulin serum, rabbit antibeefproinsulin serum and trypsin lacking chymotryptic activity (for preparation method see Wang and Carpenter, 1965).

Treatment of proinsulin with trypsin was carried out as follows: $500 \mathrm{ng}$ of proinsulin and $0.5 \mathrm{mg}$ of albumin were incubated with $1 \mu \mathrm{g}$ of trypsin in $1 \mathrm{ml}$ of TRIS-buffer $(0.05 \mathrm{M}, \mathrm{pH} 7.5)$ for $60 \mathrm{~min}$. The reaction was stopped by the addition of $50 \mu l$ of $\mathrm{N} \mathrm{HCl}$.

The following bioassay was carried out with a final dilution of the proinsulin-trypsin mixture of $1: 1000$. Parallel experiments showed that the activity of insulin remained unchanged after the same treatment and that trypsin alone did not influence the glucose metabolism of the cells under the conditions employed.

Kunitz pancreatic trypsin inhibitor (lot. no. PISF $8 \mathrm{CB})$ was obtained from Worthington Biochemical Corp. Control experiments showed that $50 \mu \mathrm{g}$ of the inhibitor completely suppressed the conversion of $0.5 \mu \mathrm{g}$ of proinsulin.

The animals, chemicals and methods used for the preparation and incubation of isolated fat cells were similar to those described by Gliemann (1967): the epididymal fat pads were disintegrated in bicarbonate buffer containing $0.4 \mathrm{mg}$ of crude collagenase per $\mathrm{ml}$ (Worthington Biochemical Corp., lot no. CLS 7IC). Whole epididymal fat pads from fed rats $(120-150 \mathrm{~g})$ were incubated in bicarbonate buffer containing $2 \mathrm{mg}$ of glucose per $\mathrm{ml}$. Some experiments were carried out with tissues from fasted rats incubated in phosphate buffer as described by Shaw and Chance (1968). Collection and counting of ${ }^{14} \mathrm{CO}_{2}$ and extraction and counting of ${ }^{14} \mathrm{C}$-glycerides followed published methods (Gliemann, 1967 and 1968).

Traditionally, the activity of insulin is expressed in units per milligram. Similarly, the results for proinsulin described in this paper have been expressed on a weight basis. However, due to its molecular weight, the theoretically maximal activity of single chain proinsulin (i.e. same activity as insulin on a molar basis) is close to $17 \mathrm{U} / \mathrm{mg}$.

The results with isolated fat cells were obtained as the mean of 4 single measurements on a 7 -point insulin standard curve.

Intervals given in tables and graphs indicate \pm 1 S.D. The experiments with epididymal fat pads were designed with the comparison between the right and the left pad of the same animal. For this reason the 
$t$-test for paired comparison was used for statistical evaluation (Table 3).

\section{Results}

\section{Characterization of the proinsulin preparations}

Fig. 1 shows that the insulin- or proinsulin-induced stimulation of the conversion of glucose $1{ }^{14} \mathrm{C}$ to ${ }^{14} \mathrm{CO}_{2}$ exhibited parallel dose-response relationships. Furthermore, the action of equivalent activities of the two proteins followed the same time course (Fig. 2). Similar results were obtained when the conversion of labelled glucose to glycerides was studied (data not shown). Figs. 1 and 2 show data obtained with the reducedreoxidized proinsulin sample; similar results were obtained with untreated proinsulin.

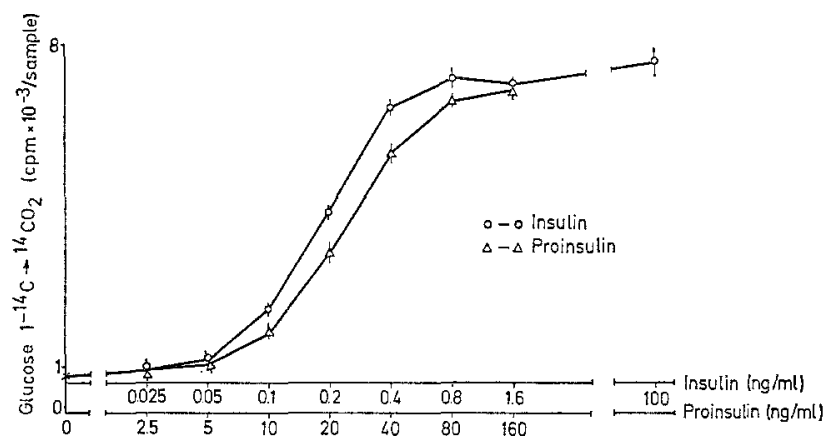

Fig. 1. Dose-response relationship for insulin and proinsulin The ordinate denotes the conversion of glucose $1^{14} \mathrm{C}$ to ${ }^{14} \mathrm{CO}_{2}$ during a $2 \mathrm{~h}$ incubation period. Note the difference in scales on the abscissa

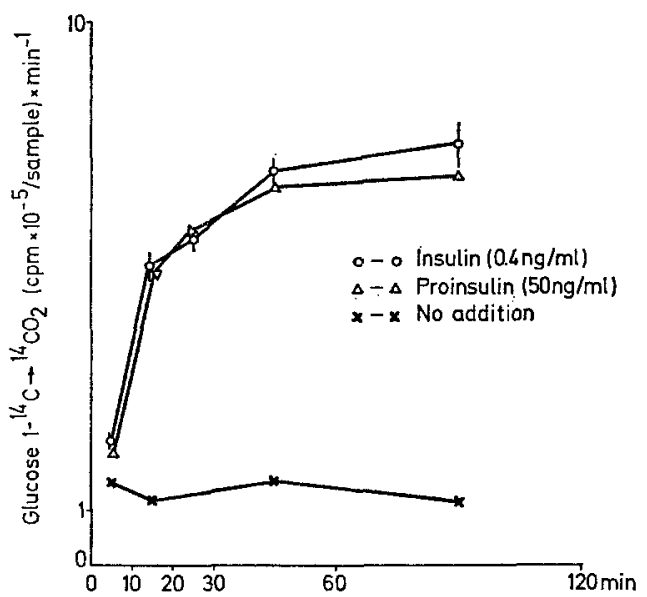

Fig. 2. Time course of the action of insulin and proinsulin The ordinate denotes the mean conversion of glucose ${ }^{1-14} \mathrm{C}$ to ${ }^{14} \mathrm{CO}_{2}(\mathrm{cpm} / \mathrm{min})$ in each time interval

Consequently, it is valid to express the activity of proinsulin in insulin units per mg of protein. It appears from Table 1 that the biological activity of beef proinsulin was 2 per cent of that of insulin, and that half of this activity was lost after reduction-reoxidation. Treatment with trypsin caused an increase in the bio- logical activity of purified proinsulin to the theoretical maximum, whereas the reduced-reoxidized proinsulin, treated identically, reached only half of this value. The activity of split chain proinsulin was about 20 per cent of that of insulin and rose to the theoretically maximal value after treatment with trypsin.

Table 1. Biological activity of single chain proinsutin, split chain proinsulin and connecting peptide before and after treatment with trypsin

\begin{tabular}{lll}
\hline & Biological activity $(\mathrm{U} / \mathrm{mg})$ \\
\hline & Glucose $1{ }^{14} \mathrm{C}^{14} \mathrm{CO}_{2}$ & $\begin{array}{l}\text { Glucose } 1 .{ }^{14} \mathrm{C} \rightarrow{ }^{14} \mathrm{C}- \\
\text { glycerides }\end{array}$ \\
$\begin{array}{l}\text { Single chain } \\
\text { proinsulin }\end{array}$ & $0.43 \pm 0.04 / 16.9 \pm 1.1$ & $0.55 \pm 0.08$ \\
$\begin{array}{l}\text { Reduced reo- } \\
\text { xidized pro- } \\
\text { insulin }\end{array}$ & $0.25 \pm 0.01 / 7.2 \pm 0.15$ & $0.26 \pm 0.03$ \\
$\begin{array}{l}\text { Split chain } \\
\text { proinsulin }\end{array}$ & $4.80 \pm 0.4 / 18.2 \pm 0.4$ & - \\
$\begin{array}{l}\text { Connecting } \\
\text { peptide }\end{array}$ & $<0.005$ & $<0.005$ \\
\hline
\end{tabular}

The numbers under the oblique line indicate the activity after treatment with trypsin. The values for the proinsulin samples are the mean activities of 5 samples weighed out and diluted individually ( \pm 1 S.D.).

Fig. 3 shows quantitative recovery of the activity of insulin in small concentrations $(0.1-0.8 \mathrm{ng} / \mathrm{ml})$ in the presence of a concentration of proinsulin or connecting peptide of $5 \mathrm{ng} / \mathrm{ml}$.

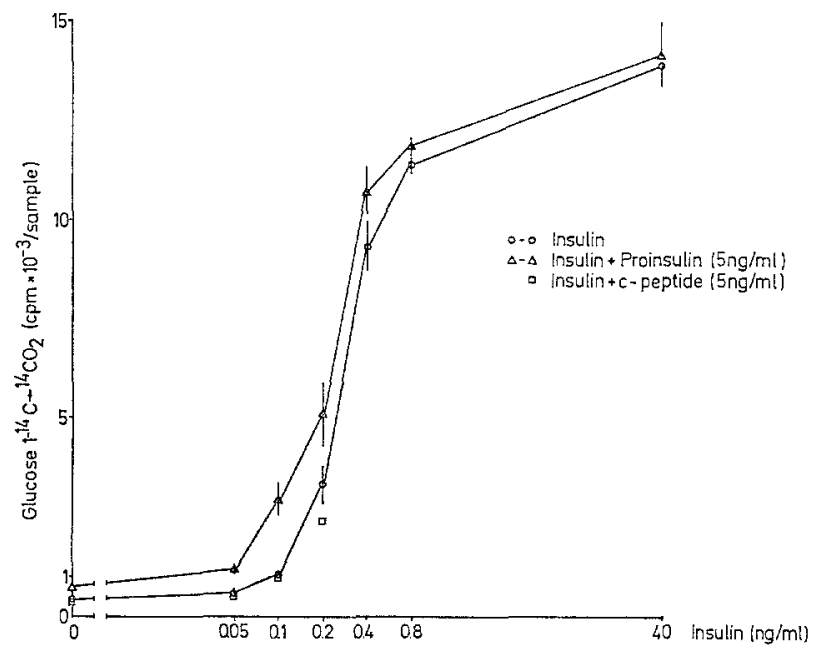

Fig. 3. Recovery of insulin activity in the presence of proinsulin and connecting peptide

Experimental conditions as in Fig. 1. Note that the activity of $5 \mathrm{ng}$ proinsulin was equivalent to $0.1 \mathrm{ng}$ of insulin (Table 1)

Fig. 4 shows that the addition of rabbit antibeefproinsulin serum suppressed the glucose conversion to $\mathrm{CO}_{2}$ by fat cells incubated with reduced-reoxidized proinsulin in contrast to cells incubated with insulin. 
The reduced reoxidized preparation was chosen for further studies in order to be certain that insulin did not contribute significantly to the measured activity (see discussion).

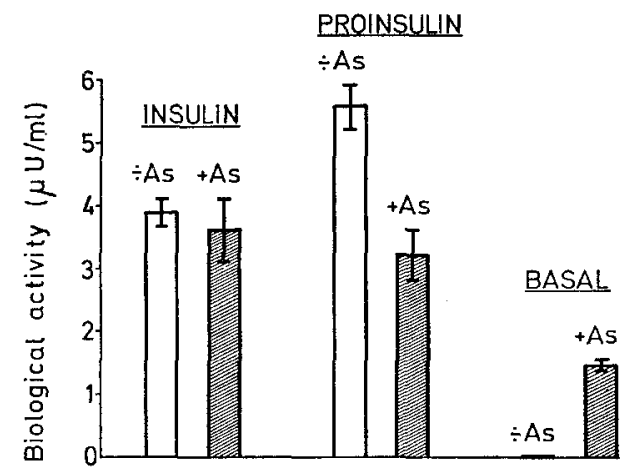

Fig. 4. Effect of rabbit antibeef-proinsulin serum on the activity of insulin and reduced-reoxidized proinsulin

The antiserum was present in the final concentration 1: 40. The activity of insulin plus antiserum was not different $(p>0.5)$ from the activity of insulin alone $(0.17 \mathrm{ng} / \mathrm{ml})$. The antiserum significantly $(p<0.001) \mathrm{de}-$ pressed the activity of proinsulin $(25 \mathrm{ng} / \mathrm{ml})$. The antiserum had an ILA of $1.4 \mu \mathrm{U} / \mathrm{ml}$ in the given dilution

\section{Is the activity on isolated fat cells caused by conversion products?}

The results shown in Fig. 4 demonstrate that such a possible conversion product would have the same immunological properties as proinsulin. A possible conversion product of single chain proinsulin could be a split chain form. However, the identical time course of the action of proinsulin and insulin (Fig. 2) excludes an activity caused by a slow conversion in the incubation medium. To test the possibility of a conversion within a few minutes, experiments were carried out with preincubation of proinsulin in buffer recovered from incubations containing fat cells in various concentrations or in cell or tissue homogenates (Table 2). No conversion to biologically more active products was registered under these conditions or in the presence of $0.2-5 \mu \mathrm{g}$ of crude collagenase per $\mathrm{ml}$. Homogenates of fat pads or of a concentrated fat cell suspension caused a decrease in the activity of both proinsulin and insulin. Finally, Kunitz pancreatic trypsin inhibitor did not suppress the activity of proinsulin (Table 3) or insulin (data not shown) on fat cells.

Is the activity on epididymal fat pads caused in part by conversion products?

This hypothesis was proposed by Shaw and Chance (1968), who found that Kunitz pancreatic trypsin inhibitor blocked the effect of porcine proinsulin on epididymal fat pads from fasted rats incubated in Krebs-Ringer phosphate buffer. Table 3 shows that these results were not confirmed in the present experiments.

Fig. 5 shows an experiment where rat epididymal fat pads were incubated with insulin and proinsulin in concentrations which showed equivalent activities on isolated fat cells. A higher activity of proinsulin on epididymal fat pads would be expected if a conversion to a more active molecule took place in the fat tissue. However, the activity ratio proinsulin: insulin on intact fat tissue was not different from that on isolated fat cells.

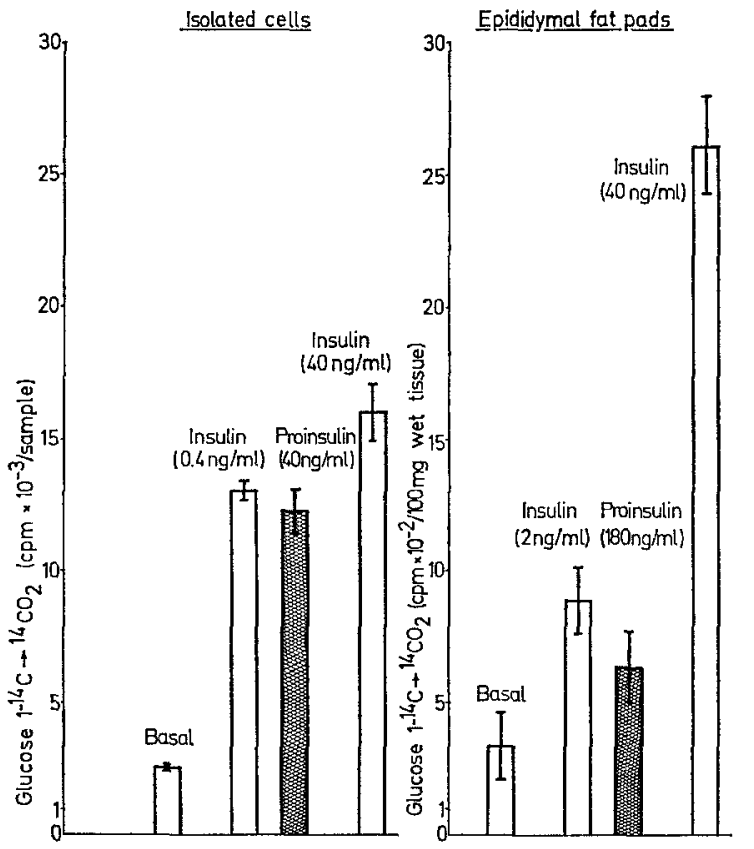

Fig. 5. Similar activity of proinsulin on isolated fat cells and epididymal fat pads

Note that the concentrations of insulin and proinsulin in the fat pad incubations were increased by a factor 5 and 4.5 , respectively

\section{Discussion}

\section{Interpretation of the results and conclusions}

Theoretically, the biological activity of the proinsulin sample could be accounted for by a contamination with approximately 1.3 per cent of insulin or 8 per cent of split chain proinsulin. However, reductionreoxidation decreased the biological activity (Table 1) as well as the immunoreactivity (Steiner and Clark, 1968) to about half of its original value, whereas the recovery of insulin under these conditions was only one-fifthieth (Steiner and Clark, 1968). Together, the findings show that only a minor fraction of the biological activity of single chain proinsulin could be caused by insulin. It is likely, therefore, that the correct biological activity of proinsulin is closer to 2 per cent than to 1 per cent of that of insulin.

The identical time course (Fig. 2) for the action of insulin and proinsulin excludes a slow conversion in the incubation medium of inactive proinsulin to a biologically active molecule. The possibility of a rapid conversion is highly unlikely, since the activity of the proinsulin sample was not affected after incubation with buffer recovered from suspensions containing 
various amounts of fat cells (Table 2). It cannot be excluded that proinsulin is converted to insulin or a similar molecule at the cell membrane or within the cell, although the inability of the cell homogenates to increase the activity of proinsulin (Table 2) speaks against this possibility.

The additive effect of insulin and proinsulin on isolated fat cells (Fig. 3) suggests that proinsulin does not act as a competitive inhibitor at the receptor sites.

The results with epididymal fat pads incubated with insulin and proinsulin in concentrations with the same effect on isolated fat cells show, that a significant conversion in adipose tissue to a more active molecule does not take place (Fig. 5). The lack of effect of Kunitz pancreatic trypsin inhibitor (Table 3) gives further support to this concept.

The findings allow the following conclusions: the biological activity $(\mathrm{U} / \mathrm{mg}$ ) of bovine proinsulin on rat epididymal fat cells or fat tissue is close to 2 per cent of that of insulin, presumably due to a smaller affinity for insulin receptors. There is no evidence for a conversion of proinsulin in fat tissue to a biologically more active molecule.

\section{The importance of a free glycine residue}

It is noteworthy that the elongation of the B-chain of the insulin molecule by the connecting peptide diminishes the activity to about 30 per cent, whereas the formation of a peptide bond between the glycine residue of the A-chain and the terminal amino acid of the connecting peptide causes a reduction to $2-3$ per cent in the activity (expressed on a molar basis). It has recently been observed that removal of the glycine residue of the A-chain causes a 90 per cent decline in the biological activity of insulin (Brandenburg et al., 1969).

\section{Results obtained by other bioassays}

Shaw and Chance (1968) and Pilkis et al. (as cited in Rubenstein et al., 1969) investigated the biological activity of porcine and bovine proinsulin on rat epididymal fat pads and rat diaphragms.

The activity of proinsulin was estimated to be 15-25 per cent of that of insulin. In the experiments of Shaw and Chance, addition of Kunitz pancreatic trypsin inhibitor abolished the activity. The lack of agreement with the present experiments remains unexplained. Results similar to those of Shaw and Chance would be obtained if either the proinsulin or the albumin contained trace amounts of trypsin.

The activity of cod proinsulin in the epididymal fat pad bioassay has been determined as less than 1 per cent of that of insulin (Grant and Reid, 1968). The effect of proinsulin on frog sartorius muscle (Narahara, as sited in Rubenstein et al., 1969) or on rat diaphragms after intraperitoneal injection (Jervell, personal communication) has been found equivalent to less than 5 per cent of that of insulin. This is in agreement with the present findings.
Table 2. Effect of preincubation of insulin and proinsulin with cell incubation medium, cell or tissue homogenate and with collagenase

\begin{tabular}{|c|c|c|}
\hline $\begin{array}{l}\text { Preincubation } \\
\text { medium }\end{array}$ & $\begin{array}{l}\text { Activity of insu- } \\
\operatorname{lin}(\mu \mathrm{U} / \mathrm{mI})\end{array}$ & $\begin{array}{l}\text { Activity of proin- } \\
\text { sulin }(\mu \mathrm{U} / \mathrm{ml})\end{array}$ \\
\hline $\begin{array}{l}\text { No treatment } \\
\text { Cell buffer } 1 \\
\text { Cell buffer } 2 \\
\text { Cell homogenate } \\
\text { Fat pad homo- } \\
\text { genate } \\
\text { Collagenase } \\
(5 \mu \mathrm{g} / \mathrm{ml}) \\
\text { Collagenase } \\
(0.2 \mu \mathrm{g} / \mathrm{ml})\end{array}$ & $\begin{array}{l}4.8 \pm 0.1 \\
4.9 \pm 0.2 \\
4.5 \pm 0.2 \\
2.1 \pm 0.1 \\
1.9 \pm 0.1 \\
4.1 \pm 0.3\end{array}$ & $\begin{array}{l}4.7 \pm 0.2 \\
4.9 \pm 0.1 \\
4.8 \pm 0.3 \\
2.8 \pm 0.1 \\
2.2 \pm 0.1 \\
3.9 \pm 0.1\end{array}$ \\
\hline
\end{tabular}

The concentration of insulin and proinsulin in the preincubation media was $4 \mathrm{ng} / \mathrm{ml}$ and $200 \mathrm{ng} / \mathrm{ml}$, respectively. After $1 \mathrm{~h}$, fractions of $50 \mu \mathrm{l}$ were transferred for insulin assay. The cell buffers 1 and 2 were recovered from suspensions containing 4.2 and $42 \mathrm{mg}$ of fat cells per ml, respectively. Homogenates were prepared from buffer containing approximately $40 \mathrm{mg}$ of cells or tissue per ml. Addition of the preincubation media without insulin or Proinsulin had no effect on fat cells

Table 3. Lack of effect of Kunitz pancreatic trypsin inhibitor on the action of proinsulin on isolated fat cells and epididymal fat pads

\begin{tabular}{|c|c|c|}
\hline $\begin{array}{l}\text { Bicarbonate buf- } \\
\text { fer; fed rats }\end{array}$ & $\begin{array}{l}\text { Isolated cells } \\
\text { (Proinsulin when } \\
\text { present: } 60 \mathrm{ng} / \mathrm{ml} \text { ) }\end{array}$ & $\begin{array}{l}\text { Fat pads } \\
\text { (Proinsulin when } \\
\text { present: 300ng } / \mathrm{ml} \text { ) }\end{array}$ \\
\hline $\mathrm{Ba}$ & $4 \pm 3$ & $475 \pm 240$ \\
\hline Proinsulin & $1034 \pm 28$ & 4814] No signifi- \\
\hline Proinsulin + inhi- & & \\
\hline bitor & $1054 \pm 7$ & $4576\left\{\begin{array}{l}\mathrm{ce} ; n=5 \\
(p>0.4)\end{array}\right.$ \\
\hline $\operatorname{Insulin}\left(10^{3} \mu \mathrm{U} / \mathrm{ml}\right)$ & $1691 \pm 84$ & $6850 \pm 2036$ \\
\hline $\begin{array}{l}\text { Phosphate buffer; } \\
\text { rats fasted } 18 \mathrm{~h}\end{array}$ & $\begin{array}{l}\text { Isolated cells } \\
\text { (Proinsulin when } \\
\text { present: } 80 \mathrm{ng} / \mathrm{ml} \text { ) }\end{array}$ & $\begin{array}{l}\text { Fat pads } \\
\text { (Proinsulin when } \\
\text { present: } 400 \mathrm{ng} / \mathrm{ml} \text { ) }\end{array}$ \\
\hline Basa & $60 \pm 4$ & $179 \pm 47$ \\
\hline Proinsu & $397 \pm 36$ & 2492 No signifi- \\
\hline $\begin{array}{l}\text { Proinsulin + inhi- } \\
\text { bitor }(50 \mu \mathrm{g} / \mathrm{ml})\end{array}$ & $410 \pm 17$ & $223\left\{\begin{array}{l}\text { rence; } n=5 \\
(p>0.2)\end{array}\right.$ \\
\hline Insulin $\left(10^{3} \mu \mathrm{U} / \mathrm{ml}\right.$ & $1354 \pm 57$ & $4290 \pm 825$ \\
\hline
\end{tabular}

The conversion of glucose ${ }^{1-14} \mathrm{C}$ to ${ }^{14} \mathrm{CO}_{2}$ is expressed either in cpm per mg cell triglycerides (isolated cells) or in cpm per $100 \mathrm{mg}$ wet weight (epididymal fat pads). Note that the proinsulin concentration was increased by a factor 5 in the experiments with epididymal fat pads.

$n$ indicates the number of paired epididymal fat pads; $p$ is the probability level derived from a paired comparison test

The material used by Shaw and Chance (1968) assayed $3 \mathrm{U}$ per $\mathrm{mg}$ by mouse convulsion assay (IRI $6 \mathrm{U} / \mathrm{mg}$ ). Puls and Kroneberg (1969) reported a blood sugar lowering activity ratio proinsulin: insulin of between $1: 4$ and $1: 2$. The action of proinsulin was more delayed than that of insulin. The magnitude and 
the time course of the blood glucose lowering effect of proinsulin cannot be explained by the biological activity found on fat cells. It is likely, therefore, that a conversion to insulin or a similar molecule takes place somewhere in the organism.

The evidence for the presence of proinsulin in the peripheral circulation is the following: blood serum contains a factor with an apparent molecular weight (Sephadex) of about 9000 and with immunological properties similar to insulin (Rubenstein et al., 1968; Roth et al., 1968).

About 30 per cent of the immunoreactive insulin (IRI) measured in human serum taken $120 \mathrm{~min}$ after an oral glucose load is such "big insulin" (Roth et al., 1968), whereas this factor accounts for a much smaller fraction of the total IRI measured 15-30 min after oral glucose. The biological activity of "big insulin" is about $0.3 \mathrm{U} / \mathrm{mg}$, which is similar to that of proinsulin (Gliemann et al., unpublished observation). Only about half of the IRI in sera taken in the fasting state appears to be accounted for by the suppressible insulinlike activity (ILA) on isolated fat cells, whereas, in serum taken 30 min after glucose ingestion, the IRI corresponds to the suppressible ILA (Gliemann et al., unpublished observations).

Finally, Yip and Logothetopoulos (1969) found that the high molecular weight IRI fraction in calf serum reacted specifically with anti-proinsulin serum from which anti-insulin had been removed by Sephadexinsulin.

'Thus it seems possible that "big insulin" is proinsulin and that it accounts for between $1 / 3$ and half of the IRI in blood serum when insulin secretion is low, but for an insignificant fraction of the IRI when the secretion is high. Recently it has been reported that proinsulin (Rubenstein et al., 1968) or "big insulin" (Roth et al., 1968) is present in high concentrations in sera from patients with newly detected juvenile diabetes. Further studies are needed on diabetic subjects to evaluate the possible role of proinsulin or "big insulin" in the various forms ot this disease.

Acknowledgement. The authors wish to thank Dr. D.F. Steiner, University of Chicago for the gift of the proinsulin preparations. Drs. A.J. Moody, O. Hallund and L. Heding, Novo Research Institute are thanked for their continuing interest and for providing us with crystalline beef insulin, insulin- and proinsulin-antisera and isolated connecting peptide. - Miss G. Schou is thanked for skilled and dependable technical assistance.

\section{References}

Brandenburg, D., Biela, M., Herbertz, L., Zahn, H.: Über den Einfluß von chomischen Veränderungen am Amino. ende der Insulinketten auf die biologische Alstivität des Hormons. 5th European association for the study of diabetes, Abstract no. 20 (1969).

Chance, R.E., Ellis, R.M., Bromer, W.W.: Porcine proinsulin: characterization and amino acid sequence. Science 161, 165-167 (1968).

Gliemann, J.: Assay of insulin-like activity by the isolated fat cell method. I. Factors influencing the response to crystalline insulin. Diabetologia 3, 382-388 (1967).

- Glucose metabolism and response to insulin of isolated fat cells and epididymal fat pads. Acta physiol. scand. 72, 481-491 (1968).

Grant, P.T., Reid, K.B.M.: Biosynthesis of an insulin precurser by islet tissue of cod (Cadus, Canarias). Biochem. J. 110, 281-288 (1968).

Puls, W., Kroneberg, G. : Experimentelle Untersuchungen über die blutzuckersenkende Wirkung von Rinder-proinsulin. Diabetologia 5, 325-330 (1969).

Roth, J., Gordon, P., Pastan, I.: "Big insulin". A new component of plasma insulin detected by immunoassay. Proc. nat. Acad. Sci, 61, 138-145 (1968).

Rubenstein, A.H., Cho, S., Steiner, D.F.: Evidence for proinsulin in human urine and serum. Lancet $1968 \mathrm{I}$, $1353-1355$.

Rubenstein, A.H., Melani, F., Pilkis, S., Steiner, D.F. Proinsulin. Secretion, metabolism, immunological and biological properties. Postgrad. med. J. 45, suppl. (1969).

Shaw, W.N., Chance, R.E.: Effect of porcine proinsulin in vitro on adipose tissue and diaphragm of the normal rat. Diabetes 17, 737-745. (1968).

Steiner, D.F.: Evidence for a precurser in the biosynthesis of insulin. Trans. N.Y. Acad. Sci. 30, 60-68 (1967).

- Clark, J.F.: The spontaneous reoxidation of reduced beef and rat proinsulins. Proc. nat. Acad. Sci. 60, 622626 (1968).

- Cunningham, D., Spigelmann, L., Aten, B.: Insulin biosynthesis: Evidence for a precurser. Science 157, $697-700$ (1967).

- Hallund, O., Rubenstein, A., Cho, S., Bayliss, C.: Isolation and properties of proinsulin, intermediate forms, and other minor components from crystalline bovine insulin. Diabetes 17, 725-736 (1968).

- Oyer, P.: The biosynthesis of insulin and a probable precurser of insulin by a human islet cell adenoma. Proc. nat. Acad. Sci. 57, 473-480 (1967).

Wang, S.S., Carpenter, F.H.: A compositional assay for insulin applied to a search for proinsulin. J. biol. Chem. 240, 1619-1625 (1965).

Yip, C.C., Lin, B.J.: Amino acid composition of bovine proinsulin. Biochem. biophys. Res. Commun. 29, 382387 (1967).

- Logothetopoulos, J.: A specific antiproinsulin serum and the presence of proinsulin in calf serum. Proc. nat. Acad. Sci. 62, 415-419 (1969).

Jørgen Gliemann, M.D., Institute of Medical Physiology C, University of Copenhagen, 71, Radmansgade, DK-2200 Copenhagen $\mathrm{N}$ 